\title{
ANALISIS KESULITAN SISWA DALAM MENYELESAIKAN SOAL CERITA PADA MATERI HIMPUNAN
}

\author{
Ufi Dwidarti ${ }^{1}$, Helti Lygia Mampouw ${ }^{2}$, Danang Setyadi ${ }^{3}$ \\ 1,2,3 Universitas Kristen Satya Wacana, Jl. Diponegoro 52-60 Salatiga \\ 202015067@student.uksw.edu
}

\begin{abstract}
This study aimed to knowing the difficulty of students in solving story problems on the set material. Indicators of difficulty in research are difficulties in understanding concepts, difficulties in applying principles and difficulties in skills. This study is a qualitative descriptive study. Subjects in this study are student of class VIIB in SMP Kristen Satya Wacana academic year of 2018/2019, that is students who have high mathematical abilities, moderate mathematical abilities, and low mathematical abilities. The results of this study indicate that subjects with high mathematical ability and mathematical ability are still experiencing difficulties in applying principles and skills, while subjects with low mathematical ability still have difficulty understanding concepts, applying principles, and skills.
\end{abstract}

Keywords: difficulty, story problems

\begin{abstract}
Abstrak
Penelitian ini bertujuan untuk mengetahui kesulitan siswa dalam menyelesaikan soal cerita pada materi himpunan. Indikator kesulitan dalam penelitian adalah kesulitan dalam pemahaman konsep, kesulitan dalam menerapkan prinsip dan kesulitan dalam keterampilan. penelitian ini adalah penelitian deskriptif kualitatif. Subjek dalam penelitian ini adalah siswa kelas VIIB SMP Kristen Satya Wacana tahun ajaran 2018/2019, yaitu siswa yang memiliki kemampuan matematika tinggi, kemampuan matematika sedang, dan kemampuan matematika rendah. Hasil penelitian ini menunjukkan bahwa subjek berkemampuan matematika tinggi dan berkemampuan matematika sedang masih mengalami kesulitan dalam menerapkan prinsip dan keterampilan, sedangkan subjek berkemampuan matematika rendah masih mengalami kesulitan dalam memahami konsep, menerapkan prinsip, dan keterampilan.
\end{abstract}

Kata kunci: Kesulitan, Soal Cerita

Matematika adalah salah satu mata pelajaran yang penting untuk dipelajari. Menurut Suherman (2003) mengatakan bahwa matematika mempelajari tentang pola keteraturan dan strukur yang terorganisasikan. Konsep-konsep matematika tersusun secara hierarkis, terstruktur, logis, dan sistematis mulai dari konsep yang paling sederhana sampai pada konsep yang paling kompleks, dalam matematika terdapat topik atau konsep selanjutnya. Senada dengan pendapat diatas, Martini, Jamaris (2014: 177) mengatakan bahwa matematika adalah suatu satu bidang studi hidup, yang perlu dipelajari karena hakikat matematika adalah pemahaman terhadap pola perubahan yang terjadi di dalam dunia nyata dan di dalam pikiran manusia serta keterkaitan diantara pola-pola tersebut secara holistik. Berdasarkan pendapat diatas dapat disimpulkan bahwa matematika adalah materi tentang pola keteraturan, struktur terorganisasikan dalam suatu satu bidang hidup yang mempelajari hakikat pemahaman terhadap pola perubahan yang terjadi di dalam dunia nyata dan dalam pikiran manusia.

Abdurrahman (2012: 204) mengemukakan bahwa 5 alasan perlunya belajar matematika yaitu sarana berpikir yang jelas dan logis, sarana untuk memecahkan masalah kehidupan sehari-hari, sarana mengenal pola-pola hubungan dan generalisasi pengalaman, sarana untuk mengembangkan kreativitas, dan sarana untuk meningkatkan kesadaran terhadap perkembangan budaya. 
Dalam proses pembelajaran di sekolah, matematika merupakan salah satu mata pelajaran yang menjadi sorotan. Hal ini dikarenakan banyaknya siswa yang mengalami kesulitan dalam menyelesaikan soal matematika khususnya dalam memecahkan masalah matematika. Secara lebih spesifik diperoleh informasi bahwa siswa mengalai kesulitan dalam menyelesaikan masalah soal cerita.

Soal cerita mempunyai peranan penting yang biasa digunakan untuk mengetahui kemampuan siswa dalam menyelesaikan soal. Soal cerita merupakan soal yang dinilai memiliki tingkat kesulitan yang lebih tinggi dibanding dengan soal matematika yang menampilkan model matematika secara langsung. Dalam soal cerita, siswa diharapkan dapat menemukan permasalahan yang harus diselesaikan dalam soal tersebut.

Abidin (Ariestina dkk, 2014) mengatakan bahwa soal cerita adalah soal yang disajikan dalam bentuk cerita pendek. Cerita yang diungkapkan dapat merupakan masalah kehidupan sehari-hari atau masalah lainnya. Soal cerita matematika adalah soal-soal matematika yang dinyatakan dalam kalimatkalimat bentuk cerita yang perlu diterjemahkan menjadi kalimat matematika atau persamaan matematika. Dalam menyelesaikan soal cerita, banyak siswa mangalami kesulitan dan kekeliruan.

Menurut Muncarno (dalam Sudirman, dkk, 2019) mengatakan bahwa siswa kesulitan dalam mengerjakan soal cerita disebabkan karena siswa kurang cermat dalam membaca dan memahami kalimat demi kalimat serta mengenai apa yang diketahui dalam soal dan apa yang ditanyakan, serta bagaimana cara menyelesaikan soal secara tepat.

Widdiharto (2008) menyatakan bahwa kesulitan dalam matematika ditandai oleh tidak mengingat satu syarat atau lebih dari suatu konsep. Hal ini menujukkan bahwa siswa masih mengalai kesulitan untuk memahami suatu materi dalam matematika. Penyebab kesulitan tersebut karena siswa tidak menguasai konsep . Selain kesulitan, siswa juga mengalami kekeliruan dalam menyelesaikan soal. Beberapa kekeliruan umum yaitu kekurangan pemahaman tentang simbol, nilai tempat, perhitungan, penggunaan proses yang keliru, dan tulisan yang tidak terbaca (Abdurrahman, 2012).

Salah satu materi dalam matematika yang siswa sering mengalami kesulitan dalam menyelesaikan soal yaitu materi himpunan. Materi himpunan memiliki tingkat kesulitan yang cukup tinggi terutama pada jenis soal cerita sehingga banyak siswa yang mengalami kesulitan dalam menyelesaikan soal cerita himpunan. Himpunan merupakan bagian yang materinya sulit dipahami siswa. Operasi yang digunakannya berbeda dengan operasi pada bilangan yang biasa digunakan sejak dari kelas I sekolah dasar. Penulisan himpunan dengan menggunakan notasi pembentuk himpunan sering tidak dipahami siswa, sehingga mereka kesulitan dalam mempelajarinya. Pratiwi (2016) dalam penelitiannya mengatakan terdapat 3 jenis kesulitan belajar yang dialami siswa pada materi himpunan, yaitu (1) kesulitan memahami soal, (2) kesulitan mentransformasi soal, dan (3) kesulitan menyelesaikan soal. Hal ini sejalan juga dengan penelitian yang telah dilakukan oleh Sholekah, dkk (2017) tentang analisis kesulitan siswa dalam menyelesaikan soal matematika ditinjau dari koneksi matematis materi limit fungsi dengan hasil yakni subjek yang memiliki tingkat koneksi matematis tinggi cenderung tidak 
memiliki kesulitan dalam menyelesaikan soal. Pada tingkat koneksi matematis sedang, siswa cenderung mengalami kesulitan pada penerapan prinsip dan menyelesaikan masalah verbal. Dan pada tingkat kemampuan koneksi matematis rendah siswa cenderung mengalami kesulitan dalam menyelesaikan soal limit fungsi yaitu pada pemahaman konsep, penerapan prinsip dan masalah verbal.

Penelitian yang telah dilakukan oleh Adilistiyo (2017) tentang analisis kesalahan siswa dalam menyelesaikan soal pada materi himpunan memperoleh hasil bahwa kesalahan-kesalahan yang dialami siswa dalam menyelesaikan soal himpunan: (1) kesalahan pemahaman; (2) kesalahan proses penyelesaian; (3) kesalahan penarikan kesimpulan. Faktor penyebab kesalahan meliputi rendahnya pemahaman siswa dalam menalar dan memahami soal materi himpunan, kurangnya ketelitian dalam menyelesaikan operasi hitung, langkah-langkah pengerjaan yang tidak sistematis, kurang melatih diri mengerjakan soal matematika, tidak terbiasa menulis kesimpulan, lemahnya kemampuan siswa dalam menafsirkan solusi kedalam konteks nyata.

Berdasarkan latar belakang di atas, maka peneliti terdorong untuk melakukan penelitian yang berjudul "analisis kesulitan siswa dalam menyelesaikan soal cerita pada materi himpunan".

\section{METODE}

Penelitian ini merupakan penelitian deskriptif kualitatif yang bertujuan untuk mengetahui kesulitan siswa dalam menyelesaikan soal cerita materi himpunan. Subjek penelitian terdiri dari 3 siswa kelas VIIB SMP Kristen Satya Wacana yang diambil secara purposive sampling yakni pengambilan sampe sumber data dengan pertimbangan tertentu (Sugiyono, 2010: 53). Pertimbangan pemilihan subjek yaitu sudah pernah belajar himpunan dan siswa yang memiliki kemampuan matematika tinggi, kemampuan matematika sedang dan kemampuan matematika rendah.

Teknik pengambilan data pada penelitian ini dilakukan dengan memberikan tes soal dan wawancara kepada subjek. Wawancara dilakukan setelah subjek menyelesai soal tes. Analisis data yang dilakukan adalah reduksi data, penyajian data dan penarikan kesimpulan. Menurut Cooney (dalam Abdurrahman, 2003: 278), terdapat 3 kesulitan, yaitu kesulitan dalam mempelajari konsep, kesulitan dalam menerapkan prinsip, kesulitan dalam keterampilan.

\section{HASIL DAN PEMBAHASAN}

Berdasarkan hasil tes dan wawancara yang dilakukan terhadap tiga subjek yaitu satu siswa berkemampuan matematika tinggi (KMT), satu siswa berkemampuan matematika sedang (KMS), dan satu siswa berkemampuan matematika rendah (KMR), diperoleh hasil sebagai berikut:

\section{Subjek berkemampuan matematika tinggi (KMT)}

Analisis kesulitan subjek berkemampuan matematika tinggi (KMT), dimulai dari kesulitan dalam konsep, kesulitan dalam menerapkan prinsip, dan kesulitan dalam keterampilan. 
Siswa KMT disini sudah mampu memahami konsep, dilihat dari cara penyelesaian siswa dalam menyelesaikan soal. Siswa mampu untuk memilah bagian-bagian yang penting pada soal. Berikut adalah jawaban subjek dalam menyelesaikan masalah nomor 1.

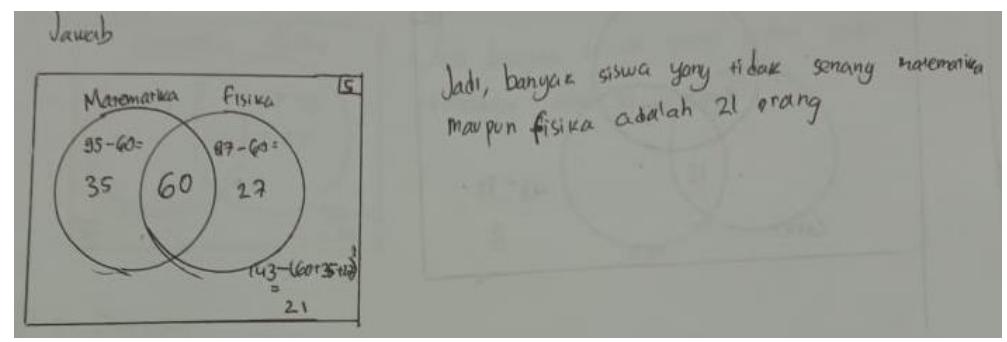

\section{Gambar 1. Jawaban KMT nomor 1}

Dapat dilihat dari jawaban subjek diatas, bahwa subjek sudah dapat memahami konsep. Subjek mampu untuk mengubah soal cerita matematika ke dalam bentuk model matematika agar memudahkan subjek dalam menyelesaikan masalah. Subjek juga mampu untuk memahami maksud dari soal yang diberikan, sehingga subjek dapat menyelesaikan soal dengan mudah.
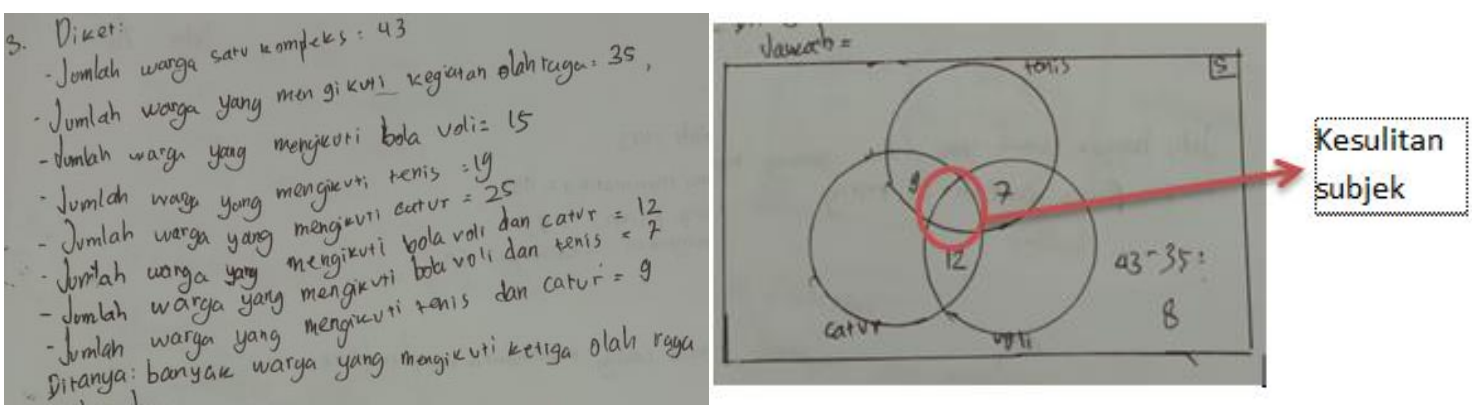

\section{Gambar 2. Jawaban KMT nomor 3}

Berdasarkan gambar 2, terlihat bahwa subjek KMT tidak menyelesaikan soal nomor 3. Hal ini menujukkan bahwa subjek KMT masih kesulitan untuk menerapkan prinsip. Subjek sudah mampu untuk menerjemahkan soal cerita ke dalam model matematika, namun subjek masih sulit untuk menyelesaikan soal.

Pada hasil wawancara, subjek KMT mengatakan bahwa hanya mengalami kesulitan pada nomor 3. Berikut adalah hasil wawancara subjek KMT.

$\mathrm{P} \quad$ : Ada yang susah ada yang nggak, susah bagian mananya?

KMT : Nomor 3

$\mathrm{P} \quad$ : Nomr 3 susah gimana?

KMT : Susah cari jawabannya.

$\mathrm{P} \quad$ : Susah cari jawabannya? Pas dijelasin di kelas kamu perhatikan gak?

KMT : Perhatiin, tapi udah lupa

P : Sekarang coba kamu perhatiin soalnya, yang kamu bingung itu yang mananya?

KMT : kan ini di suruh cari yang tengah, yang tengah itu aku lupa cara carinya. (menunjukkan gambar diagram venn pada lembar jawab). 
Berdasarkan hasil analisis dan wawancara diatas, dapat disimpulkan bahwa subjek KMT sudah mampu memahami konsep, namun masih mengalami kesulitan dalam menerapkan prinsip dan keterampilan untuk mengerjakan soal nomor 3.

\section{Subjek berkemampuan matematika sedang (KMS)}

Analisis kesulitan subjek berkemampuan matematika sedang (KMS), dimulai dari kesulitan dalam konsep, kesulitan dalam prinsip, dan kesulitan dalam keterampilan. Berikut adalah jawaban subjek dalam menyelesaikan masalah.
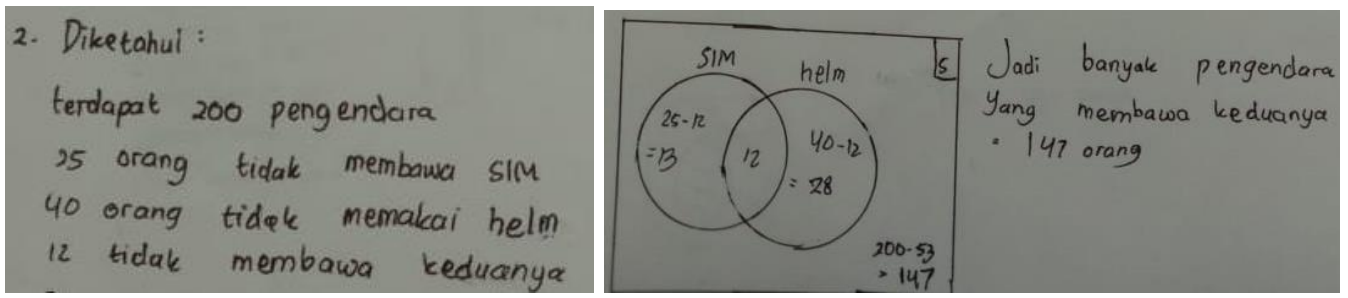

Gambar 3. Jawaban Subjek KMS nomor 2

Saat memahami konsep, untuk jawaban nomor 2 subjek sudah mampu. Subjek KMS mampu untuk memahami apa yang dimaksud dalam soal sehingga subjek bisa menyelesaikan masalah yang diberikan.
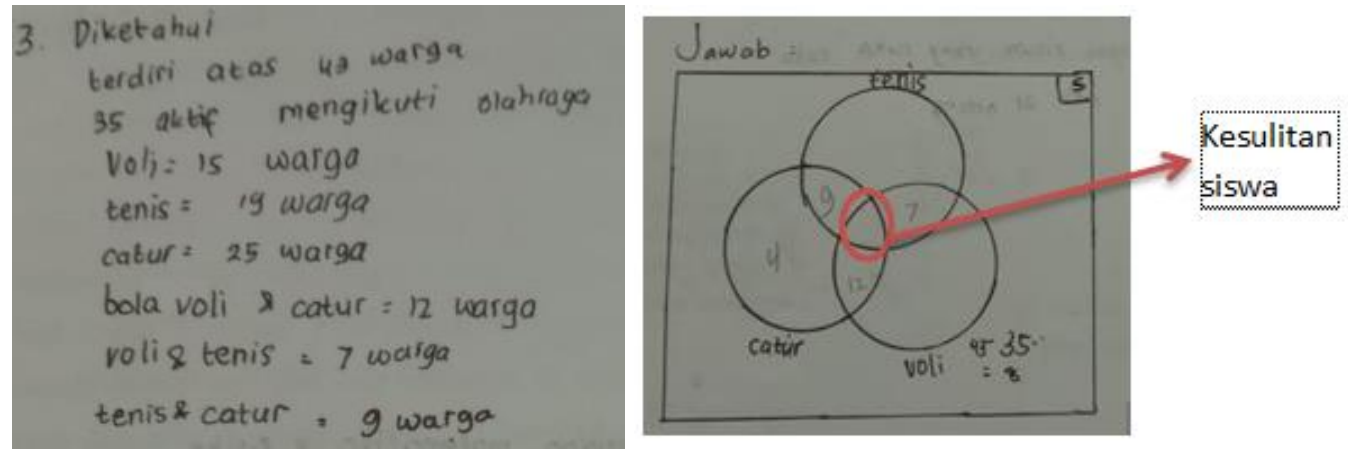

\section{Gambar 4. Jawaban Subjek KMS nomor 3}

Ketika menerapkan prinsip, untuk soal nomor 3 subjek KMS masih mengalami kesulitan. Hal ini dapat diketahui dari gambar diatas, subjek KMS belum mampu untuk menyelesaikan masalah yang diberikan. Pada keterampilan juga subjek masih mengalami kesulitan untuk soal nomor 3. Dilihat dari jawaban subjek KMS diatas, subjek belum mampu untuk menerapkan keterampilannya dalam menyelesaikan masalah untuk soal nomor 3. Pada hasil wawancara, subjek KMS mengatakan mengalami kesulitan dalam menyelesaikan masalah nomor 3.

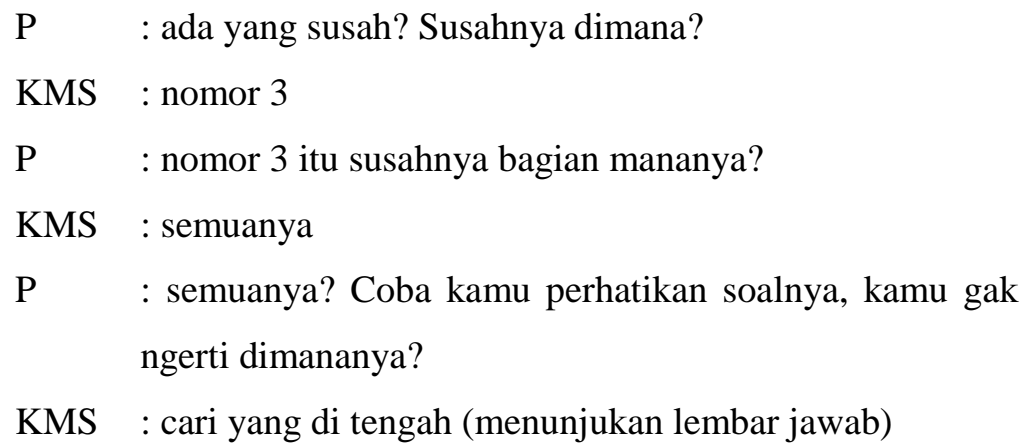


Berdasarkan hasil analisis diatas, dapat disimpulkan bahwa subjek KMS tidak mengalami kesulitan dalam memahami konsep, tetapi subjek KMS masih kesulitan dalam menerapkan prinsip dan keterampilan untuk soal nomor 3.

\section{Subjek berkemampuan matematika rendah (KMR)}

Analisis kesulitan subjek berkemampuan matematika rendah (KMR), dimulai dari kesulitan dalam konsep, kesulitan dalam prinsip, dan kesulitan dalam keterampilan. Berikut adalah jawaban subjek dalam menyelesaikan masalah.

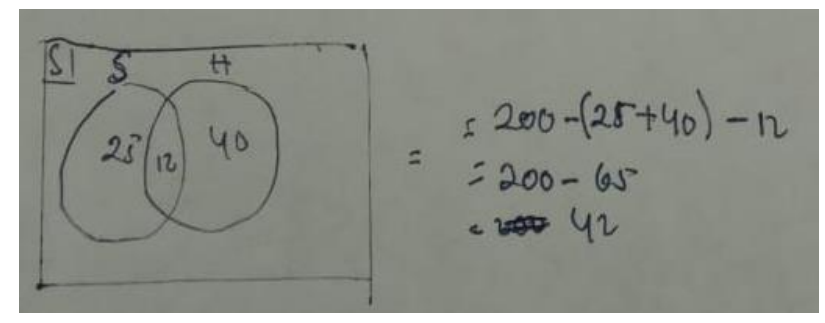

Gambar 5. Jawaban KMR

Berdasarkan gambar 5, terlihat bahwa subjek KMR disini menyelesaikan soal namun dengan jawaban yang tidak tepat. Dalam memahami konsep, subjek KMR belum mampu memahami konsep. Subjek tidak menuliskan model matematika dengan tepat. Ketika menerapkan prinsip, subjek KMR juga masih kesulitan. Hal ini dapat dilihat dari hasil jawaban subjek di atas, terlihat bahwa subjek mengerjakan soal dengan asal-asalan tidak memahami soal terlebih dahulu.

Dapat dilihat dari jawaban subjek KMR diatas, bahwa subjek KMR juga mengalami kesulitan dalam keterampilan. Subjek belum mampu untuk menerapkan keterampilannya dalam menyelesaikan masalah diatas. Pada hasil wawancara, subjek mengatakan bahwa hanya mengalami kesulitan pada nomor 3. Dilihat dari lembar jawaban, subjek tidak dapat mengerjakan nomor 3. Berikut adalah hasil wawancara subjek KMR.

$\mathrm{P} \quad$ : Menurut kamu soal ini susah apa nggak?

KMR : hmmm tidak terlalu, tapi ada yang bagian susah.

P : Tidak terlalu tapi ada yang susah? Menurut kamu yang susah itu yang bagian mana?

KMR : Nomor 3.

Berdasarkan hasil analisis dan wawancara diatas, dapat disimpulkan bahwa subjek KMR masih mengalami kesulitan menentukan konsep, menerapkan prinsip dan tidak kesulitan dalam keterampilan meskipun jawaban subjek masih kurang tepat.

Berdasarkan hasil penelitian yang telah dilakukan, diketahui bahwa siswa masih mengalami kesulitan dalam memahami materi Himpunan khususnya dalam menyelesaikan soal cerita. Cooney (Puspitasari, dkk. 2015: 6) menyatakan bahwa kesulitan dalam matematika ditandai dengan kesulitan menentukan faktor yang relevan dan akibatnya tidak mampu mengabstraksikan pola-pola. Hasil yang diperoleh sejalan dengan pendapat tersebut, bahwa siswa masih ada yang belum dapat menyelesaikan soal cerita himpunan. Penyebab kesulitan tersebut dikarenakan siswa tidak menguasai materi 
Analisis Kesulitan Siswa Dalam Menyelesaikan Soal Cerita Pada Materi Himpunan, Ufi Dwidarti, Helti Lygia Mampouw, Danang Setyadi

himpunan dan kebanyakan siswa juga cenderung lupa dengan materi yang telah diajarkan sebelumnya. Siswa juga tidak teliti dalam membaca soal sehingga belum mampu membuat model dari soal cerita yang diberikan dan belum mampu untuk menyelesaikan soal yang diberikan. Hasil penelitian diatas sejalan dengan penelitian yang telah dilakukan oleh Kartikasari (2017) dengan judul analisis kesulitan siswa dalam menyelesaikan soal cerita matematika pada siswa SMP terbukti bahwa sebesar 32,8\% siswa kesulitan menerapkan konsep khususnya dalam membedakan domain dan kodomain, 6,25\% siswa tidak mengalami kesulitan yang signifikan dalam melakukan proses perhitungan pada materi relasi dan fungsi, dan $50 \%$ siswa kesulitan menyelesaikan soal cerita karena siswa kurang mengerti maksud dari soal yang diberikan.

\section{KESIMPULAN}

Berdasarkan hasil analisis di atas, maka dapat disimpulkan bahwa subjek masih mengalami kesulitan baik dalam memahami konsep, menerapkankan prinsip dan keterampilan. Tidak hanya siswa yang memiliki kemampuan matematika rendah yang mengalami kesulitan, namun siswa yang memiliki kemampuan matematika tinggi dan kemampuan matematika sedang juga masih mengalami kesulitan dalam menyelesaikan soal cerita matematika.

Berdasarkan hasil penelitian yang telah dilakukan, peneliti menyarankan kepada guru maupun calon guru agar pada saat mengajar memperhatikan kesulitan siswa dalam materi yang diajarkan, agar siswa tidak mengalami kesulitan dalam menyelesaikan masalah soal cerita.

\section{DAFTAR PUSTAKA}

Abdurrahman, Mulyono. (2012). Pendidikan Bagi Anak Berkesulitan Belajar. Jakarta: PT Rineka Cipta.

Adilistiyo, M. R. E., \& Slamet, H. W. (2017). Analisis Kesalahan Siswa SMP Kelas VII dalam Menyelesaikan Soal Pada Materi Himpunan (Doctoral dissertation, Universitas Muhammadiyah Surakarta). [Online]. Diakses 11 April 2018.

Evijayanti, W., \& Khotimah, R. P. (2016). Analisis Kesulitan Siswa Kelas VII SMP Negeri 3 Kartasura Dalam Menyelesaikan Soal Cerita Aritmatika Sosial (Doctoral dissertation, Universitas Muhammadiyah Surakarta).

Kartikasari, R., \& Masduki, S. S. (2017). Analisis Kesulitan Siswa Dalam Menyelesaikan Soal Cerita Matematika Pada Siswa Smp (Doctoral dissertation, Universitas Muhammadiyah Surakarta). [Online]. Diakses 26 Agustus 2018.

Listiyana, F. (2012). Analisis Kesulitan Siswa Dalam Menyelesaikan Soal Rumus-Rumus Segitiga Pada Materi Trigonometri Kelas X SMAN 1 Cawas Kabupaten Klaten (Doctoral dissertation, Universitas Muhammadiyah Surakarta). [Online]. Diakses 2 Maret 2018.

Martini, J. (2014). Kesulitan Belajar: Perspektif, Asesmen, dan Penanggulangannya. Bogor: Ghalia Indonesia. 
Mudjiono dan Dimyati. (2009). Belajar dan Pembelajaran. Jakarta: PT Rineka Cipta.

Pratiwi, W. (2016). Analisis kesulitan belajar siswa pada materi himpunan SMP Muhammadiyah 10 Surakarta tahun pelajaran 2015/2016. Universitas Muhammadiyah Surakarta. [Online]. Diakses 6 Maret 2018.

Puspitasari, E., Yusmin, E., \& Nursangaji, A. (2015). Analisis Kesulitan Siswa Menyelesaikan Soal Cerita Materi istem Persamaan Linear Dua Variabel DI SMP. Jurnal Pendidikan dan Pembelajaran, 4(5).

SD, M. P. Ariestina, Yunarti, T., \& Sutiarso, S. (2014). Analisis Kesulitan Siswa Kelas VIII dalam Menyelesaikan Soal Cerita Matematika. Jurnal Pendidikan Matematika Unila, 2(2).

Sholekah, L. M. A., \& Waluyo, A. (2017). Analisis Kesulitan Siswa Dalam Menyelesaikan Soal Matematika Ditinjau Dari Koneksi Matematis Materi Limit Fungsi. WACANA AKADEMIKA: Majalah Ilmiah Kependidikan, 1(2).

Sudirman, S., Cahyono, E., \& Kadir, K. (2019). Analisis Kemampuan Koneksi Matematis Siswa SMP Pesisir Ditinjau Dari Perbedaan Gender. Jurnal Pembelajaran Berpikir Matematika, 3(2).

Sugiyono. (2010). Memahami Penelitian Kualitatif. Bandung: Alfabeta.

Suherman, E. (2003). Strategi pembelajaran matematika kontemporer. Bandung: Jica.

Widdiharto, R. (2008). Diagnosis kesulitan belajar matematika SMP dan alternatif proses remidinya. Jakarta: Depdiknas. 